\title{
Factors Inhibiting and Facilitating Japanese Teachers of English in Adopting Communicative Language Teaching Methodologies
}

\author{
Melodie Cook \\ Department of International Studies and Regional Development, Faculty of \\ International Studies and Regional Development, University of Niigata Prefecture, \\ 471 Ebigase, Higashi-ku, Niigata-City, Niigata, Japan 950-8680 \\ e-mail: cookmelo@unii.ac.jp
}

\begin{abstract}
This is a partial report on junior and senior high school Japanese teachers of English and changes in their beliefs and practices after attending a 4-month program of language and pedagogical study in Canada. Findings from this case study suggest that this group of Japanese teachers could effectively apply what they had learned abroad if they were not bound by practical constraints, external influences, or if they were teaching specifically communication-oriented classes.
\end{abstract}

Key words: communicative language teaching, in-service teacher education, constraints

In recent years, the Japanese Ministry of Education, Culture, Sports, Science, and Technology (hereinafter referred to as "the Ministry" or "MEXT") has been sponsoring junior and senior high school teachers of English (hereinafter referred to as "JTEs") to study English language and Communicative Language Teaching (hereinafter referred to as "CLT") pedagogy in English-medium countries such as the United Kingdom, the United States, and Canada. Studies (Kurihara \& Samimy, 2007; Lamie, 2001; Pacek, 1996) have found that returning JTEs' beliefs and to some extent practices may have changed, yet a number of constraints continue to obstruct their ability to do so. This paper examines the outcomes of such a program in Canada, and delves further into those factors which make it difficult for JTEs to put into practice what they have learned abroad and why, and conversely, which factors enable them to do so successfully and why.

Generally, the introduction of CLT around the world has not been without problems. A study examining the introduction of CLT in South Korea listed a number of countries (Japan among them) which had limited 
success in doing so and summarizes the reasons why ( $\mathrm{Li}, 1998)$. These constraints have been categorized by the author using Lamie's (2001) "impact area" framework, developed to highlight them within the Japanese context. Table 1 summarizes the constraints grouped into the following impact areas: personal attributes, practical constraints, external influences, awareness, and training.

\section{Table 1. Constraints Grouped by Impact Area}

\begin{tabular}{ll}
\hline Personal attributes & $\begin{array}{l}\text { Deficiencies in oral English; deficiency in } \\
\text { sociolinguistic and strategic competence: } \\
\text { traditional attitudes }\end{array}$ \\
Practical constraints & $\begin{array}{l}\text { Wider context of curriculum; traditional teaching } \\
\text { methods; class sizes \& schedule; resources and } \\
\text { equipment; lack of CLT texts; students' not }\end{array}$ \\
& $\begin{array}{l}\text { accustomed to CLT; difficulty in evaluation; too } \\
\text { much preparation time; grammar-based }\end{array}$ \\
& examinations; lack of exposure to authentic \\
& language; grammar-based syllabus; insufficient \\
funding & \\
External influences & Low status of CLT teachers; students don't \\
& perceive a need for it; student resistance, due to \\
& CLT practices being different from traditional \\
teacher/student interactions; lack of support for
\end{tabular}

Research in Japan has found that, with regards to personal attributes, JTEs tend to avoid using English in class because they lack confidence in their own ability or believe they do not possess the required proficiency to teach in English (Sato, K., 2002; Wada, 2002). Regarding practical constraints, a tradition of grammar translation persists because it is considered useful in preparing students for entrance examinations (Guest, 2000; Sato, K., 2002; Wada, 2002). Teachers are required to use textbooks authorized by the Ministry of Education and in many cases, place a high priority on keeping pace with their colleagues and teaching the same textbook topics at the same time (Sato \& Kleinsasser, 2004). 
As for external influences, since teachers work as a team, their practices are reinforced by others, especially in the hierarchically-organized Japanese society, where junior teachers are expected to conform to the teacher practices of their seniors, and fear challenging students' attitudes towards examination-oriented English classes (Sato, 2002). In addition, English teachers tend to feel that they do not receive support from colleagues or administrative bodies. With regards to training, Japanese English teachers generally receive little or no information about CLT (Scholefield, 1997) and may not be enthusiastic about workshops due to time constraints or a lack of interest (Sato, K., 2002; Takaki, 2002).

Studies (Browne \& Wada, 1998; Lamie, 2001) have revealed that English teachers in Japan feel that they had not been adequately trained for teaching anything beyond Grammar/Translation. Training is often restricted to domestic experiences which sometimes lack adequate English components (Nagasawa, 2004). Most teachers have majored in English literature or linguistics in university, have not been required to take courses in second language acquisition theory, second language teaching methodology and techniques, but many had taken courses in Grammar Translation Methodology. All have had what some have characterized as insufficient and sometimes inappropriate practicum experience (Nagasawa, 2004; Yonesaka, 1999), as well as few opportunities to attend in-service training. As a result of the short practicum, the teachers tended to perpetuate the methodological status quo; that is, to teach using grammar translation methods. They also reported feelings of dissatisfaction with their training, especially since it generally took place through Japanesemedium courses, and many felt they needed to go outside the university to learn more about how to teach English.

Study abroad programs for Japanese teachers enable them to improve their English skills and introduce them to current ELT pedagogy. However, after returning to Japan they report difficulty in implementing what they have learned on these programs, particularly student-centered lessons. They are aware of a gap between CLT and their students' and colleagues' expectations of what should be taught and learned in the Japanese secondary school English classroom. They are afraid of being ostracized by more senior teachers attempting communicative innovations and feel they need to wait until they had achieved more seniority.

Although teachers indicated that they had gained many personal benefits from their M.A. study and practicum experience, "[t]he expertise they have gained in their graduate program in terms of linguistic knowledge and teaching methods may not be valued and perhaps may 
even be viewed by some as a threat” (McKay, 2000, pp. 66-67). While McKay's study focused on Japanese graduate students who paid to study abroad on their own initiative, another route for in-service JTEs to study pedagogy is to be sponsored for overseas study by the Ministry of Education.

Previous studies of the MEXT program (Kurihara \& Samimy, 2007; Lamie, 2001; Pacek, 1996) (one year or six-month duration) in the United Kingdom and the United States have found that while teachers felt positive about their ability to implement what they were learning while they were still in the host country, a number of constraints prevented them from doing so fully after returning to Japan. Table 2 summarizes areas where changes occurred or highlights reasons why changes was constrained as reported by these studies.

Table 2. Reported Change and Reasons for Lack of Change by Previous MEXT Program Participants

\begin{tabular}{|c|c|}
\hline $\begin{array}{c}\text { Reported change in classroom } \\
\text { practice }\end{array}$ & $\begin{array}{l}\text { Reasons for no change in } \\
\text { classroom practice }\end{array}$ \\
\hline $\begin{array}{l}\text { - More pair work and group work } \\
\text { - More English used by the teacher } \\
\text { in class } \\
\text { - More emphasis on developing } \\
\text { - students' communicative skills } \\
\text { - } \text { More methods and materials used } \\
\text { - } \text { related activities } \\
\text { - A raised understanding of the } \\
\text { value of English as a useful tool } \\
\text { for communication } \\
\text { - A gain in confidence in their } \\
\text { improvement of current teaching } \\
\text { - } \text { practice } \\
\text { An understanding of } \\
\text { American/British culture }\end{array}$ & $\begin{array}{l}\text { - Entrance examination preparation } \\
\text { pressures } \\
\text { - Resistance from students, parents, } \\
\text { and colleagues } \\
\text { - Ministry-mandated textbooks } \\
\text { containing “unnatural” or } \\
\text { "unauthentic sentences” } \\
\text { - Institutional culture and beliefs } \\
\text { - Community and local pressures } \\
\text { - Large class sizes } \\
\text { - Cultural differences in educational } \\
\text { environments in the United States } \\
\text { - Und Japan } \\
\text { - Uncertainty about how to adapt } \\
\text { American practices to Japanese } \\
\text { situations } \\
\text { - Classroom decision-making } \\
\text { processes were strongly } \\
\text { influenced bv colleagues }\end{array}$ \\
\hline
\end{tabular}


As the table indicates, although some teachers reported changing some aspects of their practice, they were still inhibited by a number of practical constraints and external influences.

The Canadian program is worthy of study because program planners and instructors challenged MEXT's goals and attempted to create a program they felt was more suited to JTEs' needs. In 2005, instead of the 4000-word research paper MEXT usually asked host universities to help JTEs prepare, the University of Canada proposed a professional development dossier (PDD), which would contain a shorter research paper and a collection of classroom activities developed by each teacher, believing that the demands of a longer research paper were too demanding for JTEs, that they were teachers rather than academics, that time would be more efficiently spent enabling teachers to focus on practical aspects of teaching. Therefore, the orientation of this program shifted from a theoretical to a practical one.

At the end of the program in Canada, teachers listed a number of practices they believed they could incorporate into their classrooms. The purpose of this study was to answer the following questions:

1. Which practices were JTEs able to successfully incorporate or continue incorporating six months after returning to Japan? Which factors facilitated incorporation?

2. If they were unable to incorporate practices they believed they could, or had abandoned some practices, what were the factors inhibiting incorporation?

\section{METHODS}

This research is part of an observational case study, focusing on the 4month pedagogical portion of a 6-month program of language and pedagogical study in Canada. This particular study focuses on preprogram, in-program, immediate post-program, and 6-month follow-up periods. Data collection methods were varied and included document collection, questionnaires, observations, and oral interviews based on closed- and open-ended questionnaires (Bogdan \& Biklen, 2007; Cresswell, 2003).

\section{The Program}

According to program description at the host Canadian university, the primary objective of the program was "to promote communicative 
approaches to language teaching... [which] help learners develop the ability to use the language accurately, appropriately, and effectively for communication" (Institute, 2007, p. 4). The professional development dossier mentioned above would:

- a 20-page essay on an identified critical teaching problem and a discussion of how communicative language teaching could address it;

- an "action file" of approaches, lesson plans and activities to "address the teaching problem;

- a PowerPoint presentation on the same, and

- a short report on the "perceived improvement of the participant's English-language skills” (p. 5).

Teachers also kept reflective teaching journals, prepared poster presentations, visited schools, observed classes in the university's Intensive English Program, and took TOEFL and CanTESTs to gauge their receptive and productive skills before and after the commencement of the program. They attended lectures by guest speakers, attended classes four mornings a week; went on field trips, did class observations and project preparation, among other activities.

With a goal of balancing theory and practice, the University of Canada's 4-month program consisted of five modules: PDD/Testing and Evaluation (academic writing/presentation skills/testing techniques), Pedagogical Tools (teaching methods), Multimedia Tools, Productive Skills (speaking and writing), and Receptive Skills (reading and listening).

Several of the host instructors expressed the belief that they were not expecting wholesale changes and that they would be satisfied with if JTEs made even small modifications to their beliefs and practices. During a preprogram interview, one of the instructors said, "I think if they can come out of here with the confidence that they could use English and that they could find a way for their students to use it in the classroom a little bit...it'll be a huge thing for them.”

\section{Participants}

The participants were five teachers who formally consented to take part in the research from the beginning of the program in Canada to the first follow-up phase of data collection. ${ }^{1}$ Teachers' ages were recorded as those at the time of meeting in late August, 2007. "Self-selected" means

\footnotetext{
${ }^{1}$ Pseudonyms were used to protect anonymity.
} 
that the participant applied to attend, while "Board-selected" means that the participant was obliged to attend by his or her board of education. Table 3 summarizes information about the participants. As the table indicates, two of the five participants have education-related degrees. The others have degrees in linguistics or literature. The teachers have between 11 and 19 years of experience, and from more than half applied to attend the program.

Table 3. Canadian MEXT Program Participants

\begin{tabular}{|c|c|c|c|c|c|}
\hline Name & Age & B.A. Degree & $\begin{array}{c}\text { School } \\
\text { currently } \\
\text { teaching at }\end{array}$ & $\begin{array}{c}\text { Years' } \\
\text { teaching } \\
\text { experience }\end{array}$ & $\begin{array}{c}\text { Selection to } \\
\text { Program }\end{array}$ \\
\hline Mr. T. & 41 & $\begin{array}{l}\text { English } \\
\text { Linguistics }\end{array}$ & $\begin{array}{l}\text { Public } \\
\text { academic high } \\
\text { school }\end{array}$ & 19 & $\begin{array}{l}\text { Board- } \\
\text { selected }\end{array}$ \\
\hline Ms J. & 38 & $\begin{array}{l}\text { English } \\
\text { Education }\end{array}$ & $\begin{array}{l}\text { Public } \\
\text { academic high } \\
\text { school }\end{array}$ & 13 & Self-selected \\
\hline Mr. H. & 37 & $\begin{array}{l}\text { English } \\
\text { Education }\end{array}$ & $\begin{array}{l}\text { Public junior } \\
\text { high school }\end{array}$ & 14 & $\begin{array}{l}\text { Board- } \\
\text { selected }\end{array}$ \\
\hline Ms H. & 36 & $\begin{array}{l}\text { English } \\
\text { Literature }\end{array}$ & $\begin{array}{l}\text { Public junior } \\
\text { high school }\end{array}$ & 13 & Self-selected \\
\hline Ms D. & 34 & $\begin{array}{l}\text { English and } \\
\text { American } \\
\text { Literature }\end{array}$ & $\begin{array}{l}\text { Public } \\
\text { academic high } \\
\text { school }\end{array}$ & 11 & Self-selected \\
\hline
\end{tabular}

\section{Educational Background, Practicum, and Teaching Experience}

Of this group, only Ms J. and Mr. H. held undergraduate degrees in English education and thus were the only ones who took a number of pedagogically-related courses as well more than one teaching practicum. Of all the participants, Mr. H. was the only teacher one of whose practicum periods occurred in the environment he envisioned working (junior high school). Mr. T., Ms J., and Ms D., all high school teachers, undertook their practicums at the junior high school level, while Ms H., a junior high school teacher, did her practicum in a high school setting. Although Ms H. said that her university's teaching license program had a strong influence on her current practice, the others rated their university training as having had no, little, or some influence.

All of the teachers taught in at least two and were currently teaching between 13-15 classes per week with generally more than 20 students in a 
class. Most teachers worked with Assistant Language Teachers (ALTs); however, some, like Ms H., only worked with an ALT in the class twice a month.

\section{Data Collection and Analysis}

Multiple methods were used for data collection, including questionnaires (pre- and post-program), reflection journals and class observations. Data were analyzed following Cresswell's (2003) generic guide for analysis and interpretation. Data were collected, transcribed, and coded using NVivo software in order to discover emergent themes.

\section{FINDINGS AND DISCUSSION}

\section{Immediate-post Program - Universal Themes}

Table 4 summarizes theories, practices, or other items teachers felt they would be able to incorporate into their classrooms or would influence their classroom practice immediately upon returning to Japan. Items are grouped into three categories: theory, practice/organization, and other (class visits, guest speakers, etc. - items not specifically taught in any one course). If a theory or practice was mentioned more than once, the number of times it was mentioned is written in parentheses.

Table 4. "Before" -- Immediate-Post Program Universal Themes

\begin{tabular}{|c|c|c|}
\hline Theory & $\begin{array}{l}\text { Classroom } \\
\text { Practice/Organization }\end{array}$ & Other \\
\hline $\begin{array}{l}\text { Activating background } \\
\text { schema (4) } \\
\text { Task-based learning (2) } \\
\text { No one “best” method } \\
\text { Motivational concepts } \\
\text { Communicative theory } \\
\text { Topic choice } \\
\text { Transfer of activities } \\
\text { among skills } \\
\text { Information-gap } \\
\text { Explaining the purpose } \\
\text { of activities to students } \\
\text { Characteristics of good } \\
\text { tests }\end{array}$ & $\begin{array}{l}\text { Communicative activities } \\
\text { based on an individual } \\
\text { teachers' textbook (2) } \\
\text { Pair work } \\
\text { Debating } \\
\text { Grammar games } \\
\text { Writing activities } \\
\text { Speaking activities } \\
\text { Listening activities } \\
\text { Poster presentations } \\
\text { Group discussions } \\
\text { Movies and songs }\end{array}$ & $\begin{array}{l}\text { School visits } \\
\text { Presentations by other } \\
\text { teachers } \\
\text { Trips } \\
\text { How to behave as a } \\
\text { teacher (smiling, } \\
\text { praising) } \\
\text { Giving students time } \\
\text { to think/express } \\
\text { themselves }\end{array}$ \\
\hline
\end{tabular}


As the table indicates, four teachers felt they could activate students' background schema. Two believed task-based learning was applicable to their teaching situations, and two expected to be able to use the communicative activities they had created themselves. The remaining responses varied.

\section{“After” -- Six-month Follow-up}

Table 5 summarizes what teachers said they were able to incorporate "as is" (as they'd developed in Canada) incorporate with modifications, or unable to incorporate into their classroom practices. Following the summary is a detailed presentation of each case.

Table 5. Incorporation of Theories or Practices

\begin{tabular}{|c|c|c|c|}
\hline $\begin{array}{c}\text { Incorporated } \\
\text { "as is" }\end{array}$ & $\begin{array}{l}\text { Incorporated } \\
\text { with } \\
\text { modifications }\end{array}$ & $\begin{array}{l}\text { Unable to } \\
\text { incorporate }\end{array}$ & $\begin{array}{c}\text { Rationale for } \\
\text { inability to } \\
\text { incorporate }\end{array}$ \\
\hline Mr. T. Readers' Theatre & $\begin{array}{l}\text { Pre-reading } \\
\text { activities } \\
\text { Pre-writing } \\
\text { activities }\end{array}$ & $\begin{array}{l}\text { Task-based } \\
\text { learning } \\
\text { Five } \\
\text { communicative } \\
\text { activities related } \\
\text { to the textbook }\end{array}$ & $\begin{array}{l}\text { Entrance } \\
\text { examination } \\
\text { demands } \\
\text { Demands to } \\
\text { keep pace with } \\
\text { colleagues } \\
\text { Silent students } \\
\text { A belief in own } \\
\text { language } \\
\text { insufficiency } \\
\text { Student } \\
\text { passivity }\end{array}$ \\
\hline $\begin{array}{l}\text { Ms J. Sound test } \\
\text { construction } \\
\text { Listening cloze } \\
\text { Pre-, while, and } \\
\text { post-reading } \\
\text { activities } \\
\text { Classroom } \\
\text { English } \\
\text { CALL activity } \\
\text { Rubrics for }\end{array}$ & & & \\
\hline
\end{tabular}




\begin{tabular}{|c|c|c|c|}
\hline $\begin{array}{l}\text { scoring oral } \\
\text { presentations }\end{array}$ & & & \\
\hline $\begin{array}{l}\text { Mr.H. Writing letters } \\
\text { Interesting } \\
\text { speaking } \\
\text { activities } \\
\text { Speech-making } \\
\text { Student-made } \\
\text { flashcards } \\
\text { Games } \\
10 \text { criteria for } \\
\text { effective teaching } \\
\text { CLT checklist }\end{array}$ & & $\begin{array}{l}\text { Skimming and } \\
\text { scanning }\end{array}$ & $\begin{array}{l}\text { Too difficult for } \\
\text { junior high } \\
\text { school students } \\
\text { Demands to use } \\
\text { prescribed texts }\end{array}$ \\
\hline $\begin{array}{l}\text { Ms H. Picture diary } \\
\text { Self-history } \\
\text { Skimming and } \\
\text { scanning } \\
\text { Test evaluation }\end{array}$ & $\begin{array}{l}\text { P.D.D. } \\
\text { activities }\end{array}$ & & \\
\hline Ms D. Poster project & & $\begin{array}{l}16 \text { speaking } \\
\text { activities }\end{array}$ & $\begin{array}{l}\text { Entrance } \\
\text { examination } \\
\text { demands } \\
\text { A new textbook }\end{array}$ \\
\hline
\end{tabular}

As the table indicates, Ms J. and Mr. H. seem to have been the most successful at incorporating what they had learned in Canada, followed by Ms H. Mr. T. seems to have had some success, but felt a need for much modification and Ms D. seems to have been the least able to incorporate what she had learned in the program. These results suggest that some teachers in this group were constrained from adopting CLT methodologies into their classroom practices due to practical constraints, external influences, and other factors such as student levels and teacher transfers. Each of these will be discussed in turn below.

\section{Practical Constraints}

\section{Entrance Examinations}

Mr. T and Ms D. both reported feeling prevented from immediately incorporating many of the activities they had prepared in Canada due to 
pressures to help their students prepare for university examinations. Both felt that they would be better able to do so in later semesters. Conversely, the absence of this pressure may have been the reason why Ms J., Mr. H. and $\mathrm{Ms} \mathrm{H}$. appeared successful at implementing what they had learned in Canada; Ms J. was responsible for teaching second-year high school students who are still one year away from examinations and both $\mathrm{Mr}$. $\mathrm{H}$. and Ms $\mathrm{H}$. taught junior high school students.

Although In Japan high-stakes university entrance examinations are said to provide opportunities for the "best talent" to be able to attend prestigious universities and prevent nepotism (Kariya \& Dore, 2006), they constrain the teaching of English for communication in many ways. The test impact of entrance examinations, especially in terms of gate keeping mechanisms (McNamara, 2000) is strong and has effects on what teachers and students do in the classroom. According to Gorsuch (2001), teachers feel it is their duty to prepare students for these examinations by having students practice translation exercises, take vocabulary tests, and develop knowledge about English rather than improving their ability to actually communicate in it. For many students, especially those at academic high schools, this is their precise purpose for attending school (Matsumoto, 1994). At present, most students wishing to enter universities must sit for the nation-wide Center Test, administered by the Education Ministry's College Examination Center (others may apply for the "entry-byrecommendation system" or based on sports club activities) (Okano \& Tsuchiya, 1999). After doing so, students then sit in-house tests made by individual public and private universities.

\section{Appropriate Courses}

Mr. T. mentioned that had he been teaching the Oral Communication class, it would have been easier for him to try out the five communicative activities he had developed in Canada. Ms J., who was teaching the Oral Communication class, appeared to be very successful in using all the activities she had created. The Oral Communication class, offered in all high schools, is an elective course, usually taken by smaller numbers of students. In those classes, teachers have a textbook to follow, but are freer to try different kinds of activities in class.

\section{Ministry-Mandated Textbooks}

In Japan, public school teachers are required to use textbooks approved by the Ministry of Education (Ishikida, 2005). Mr. H. said that he was 
unable to implement some of the activities he had prepared in Canada, because they were more difficult than the level of Ministry-mandated textbook he was required to use. In addition, although Ms D. had made 17 communicative activities based on her textbook, she was only able to use one which was not dependent on the content of her textbook. The reason for this was that her textbook changed, rendering the activities she had prepared abroad unusable.

\section{Classroom Culture}

Mr. T. said that it was difficult for him to use some pre-reading activities he had prepared in Canada, because his students were unusually silent and he had no way of determining if they were learning what he was teaching, unless he did so in Japanese. These students also tended to regarded products as more important than processes, and thus would copy answers from each other, rather than use English to get to their answers. While it is difficult to account for this particular class' reticence - Mr. T. said that he had never had such a silent class before - it is likely that students focused on learning outcomes since they were in an academic school ultimately preparing for university entrance examination success, as noted above.

\section{External Influences}

\section{Pressures to Conform to Standard Practices}

Mr. T. said that it was difficult for him to do task-based learning because he had a limited amount of teaching time and had to keep pace

with his colleagues. With regards to time, teachers in Japan have many duties in addition to heavy teaching loads and teach a 5-6 day workweek, also working during summer vacation. According to Okano \& Tsuchiya (1999), junior high school teachers teach an average of 19.7 hours per week, while senior high school teachers teach an average of 16.8 hours per week; above this, they are also responsible for supervising after-school activities, counseling, and giving supplementary lessons for entrance examinations.

Mr. T. highlighted the importance of keeping pacing with colleagues when talking about the pre-pedagogical language course he attended before 
going to the University of Canada. In that course, he and his colleagues were placed in different classes at the same level; however, the demands of each class were quite different, with one instructor calling for a 25-page essay, while the other did not make such demands. While this was not a problem in a Canadian context, he said it would be in Japan.

Socialization in schools is a very influential factor on Japanese teachers' practices generally (K. Sato \& Kleinsasser, 2004). Generally, teachers who fail to form rapport with colleagues by not conforming to group norms, may be faced with “... not only an uncomfortable work environment but also a denial of valuable opportunities for professional development" (Okano \& Tsuchiya, 1999, p. 175; Yonesaka, 1999). With regards to English teaching in particular, research found that an unwillingness to oppose their colleagues' methods forced teachers to use grammar-translation techniques. Although they had various beliefs about the best ways to teach English, they were prevented from doing so because of their work environments and in the end, taught what they felt was necessary, rather than what they thought was right (O'Donnell, 2005).

On the other hand, those teachers who reported being successful at implementing what they had learned in Canada were not required to work with colleagues (Ms H.), worked with colleagues who were like-minded, such as Mr. H. whose head teacher at school also took part in the MEXT program in the United States, or although required to use the same textbook as their colleagues, felt free to supplement as they liked (Mr. H. and Ms J.).

\section{Other Influences}

\section{Incompatibility with student levels}

Mr. H. reported that what he had prepared in Canada was too difficult for his current students and more suitable for senior high school students. An implication here is that while what is learned in Canada may be inappropriate for a teacher's current class, it may be of use in another grade level.

\section{Teacher transfers}

In Japan, teachers are regularly transferred every several years. Novice teachers spend their first three years at one school and after that on average of up to five years at any one school in order that they be exposed to 
diverse types of schools, where they hone their skills and learn about their strengths and weaknesses (Okano \& Tsuchiya, 1999). However, because Ms D's situation had been transferred to a new school immediately prior to entering the MEXT program, she had no idea what kinds of students she would be meeting. It was therefore difficult for her to formulate and focus her professional development dossier.

\section{School as Service Provider}

A strong underlying reason why teachers seem to be giving into the demands of their students, colleagues, and society in general is that paying parents (at the high school level) expect to be guaranteed that their children will succeed on entrance exams. Because of this economically-motivated pressure,

“... private sector interests in education have grown, and they now hinder teachers' efforts to fulfill a "public mission" whereby teachers are entrusted to educate children in order to construct a democratic society. Parents and students have become consumers of educational enterprises, and if the services offered are deemed unsatisfactory, teachers are held responsible by the general public.” (M. Sato \& Asanuma, 2000, p. 108).

In the end, teachers are forced to provide a specific service or face public criticism. Mr. T. referred to a case some years ago where a school had falsified students' records saying that students had taken certain general subject-area courses, when in fact, students had only focused on courses that would prepare them for entrance examinations (Hongo, 2006). Mr. T. seemed to think that the school had done nothing wrong. He said, "I guess if we had taught ... world history to the students who are not taking world history on the exam, they would complain about that, because this is useless for them... And the parents will also start complaining."

\section{Surmounting Obstacles: A Background in Education}

It appears that Ms J., Mr. H., and Ms H. were the most successful at adopting what they had learned abroad. Even though Ms J. worked at highacademic school, and was bound by the same practical constraints and external influences as her colleagues in the MEXT program, she appeared 
able to surmount them rather than be hindered by them. Perhaps her success, as well as that of Mr. H. may have been in part due to the fact that they both majored in education in university, supporting the finding that “... the embedding of new practices in teachers' existing professional culture will not be ... [done] without appropriate readjustment to the processes and content of initial language teacher training” (Wedell, 2003, p. 447).

In Japan, teachers may be granted teaching certificates after graduating from general BA programs or from colleges of education. In fact, less than half of them received their degrees from colleges of education (Okano \& Tsuchiya, 1999). Pedagogically-related courses such as principles of education, educational administration, educational psychology, curriculum and instruction, etc. are offered in colleges of education, but not necessarily in other certificate-granting colleges (Nagasawa, 2004; Sato, M., \& Asanuma, 2000). Thus, while all teachers taking part in the MEXT program held teaching certificates, only a few of those teachers had taken a significant number of educationally-related courses.

\section{CONCLUSION AND SUGGESTIONS}

This study suggests that practical constraints, external influences, and other factors such as school levels and school transfers may continue to constrain JTEs from implementing what they have learned abroad. Underlying these constraints is the reality that all of them stem from the same source: teachers feel compelled to deliver a specific service regardless of their desire to truly educate students because of a number of institutional pressures.

However, the removal of these same constraints and the possibility to teach communication-related classes facilitates JTEs in adopting practices learned in overseas training. In addition, those teachers coming from education-related backgrounds may be likely to have the most success in overcoming constraints and adopting a greater number of methodologies, since they are adding to a repertoire of teaching strategies, and not learning about them for the first time.

This study seems to indicate that JTEs are able to incorporate some of what they have learned abroad, even if it is only one activity, such as in Ms D.'s case. In addition, even though some teachers were unable to implement what they'd learned at their current school, chances are they 
may be able to at a future placement if favorable conditions, such as those listed above, exist.

Another suggestion for overseas trainers in general is that while trainers in this particular program seemed to have achieved their goals of having teachers make small changes, they still need to be mindful of the kinds of practical constraints and external influences that exert pressure on JTEs and not ask of them anything that will likely be difficult to implement once the teachers return to Japan. Time pressures and the need to use mandated materials are very real constraints and activities requiring teachers to spend a lot of time preparing or that take away time from using required materials will likely be abandoned.

Another implication is that if there is no connection between MEXT's communicative goals and the realities of entrance examinations, it may be difficult for teachers to make their classes more communicatively-oriented. Unless students are required to demonstrate oral proficiency on entrance examinations, it may be unlikely that teachers will change their practices.

A final, and rather important suggestion, is for those responsible for providing teacher training domestically. Perhaps more consistent and comprehensive training at the university level will help teachers embed new practices, thus making the government's investment in overseas teacher in-service training bear fruit.

\section{REFERENCES}

Bogdan, C., \& Biklen, S. K. (2007). Qualitative research for education: An introduction to theories and methods. Boston: Pearson.

Cresswell, J. W. (2003). Research design: Qualitative, quantitative, and mixed methods approaches. Thousand Oaks: Sage Publications.

Guest, M. (2000). "But I have to teach grammar!" . Retrieved May 12, 2009, from http://www.jalt-publications.org/tlt/articles/2000/11/guest

Hongo, J. K. S. (2006). Teachers, experts say schools had to ax classes for seniors. The Japan Times Online. Retrieved May 12, 2009, from http://search. japantimes.co.jp/cgi-bin/nn20061028a1.html

Institute, U. o. C. S. L. (2007). MEXT 2007 Professional development program for EFL teachers.

Ishikida, M. Y. (2005). Japanese Education in the 21st Century. New York: iUniverse. 
Kariya, T., \& Dore, R. (2006). Japan at the meritocracy frontier: From here, where? The Political Quarterly, 77(1), 134-156.

Kurihara, Y., \& Samimy, K. K. (2007). The impact of a U.S. teacher training program on teaching beliefs and practices: A case study of secondary school level Japanese teachers of English. Japan Association for Language Teaching, 29(1), 99-122.

Lamie, J. M. (2001). The impact of in-service training on teachers of English in Japan. New York: Nova Science Publishers, Inc.

Li, D. (1998). "It's always more difficult than you plan and imagine": Teachers' perceived difficulties in introducing the communicative approach in South Korea. TESOL Quarterly, 32(4), 677-703.

McKay, S. (2000). An investigation of five Japanese English teachers' reflections on their U.S. MA TESOL practicum experience. JALT Journal, 22(1), 4668.

McNamara, T. (2000). The social character of language tests. In Language testing (pp. 67-77). Oxford: Oxford University Press.

Nagasawa, K. (2004). Teacher training and development. In V. Makarova, \& T. Rodgers (Eds.), English language teaching: The case of Japan. Munich: Lincom Europa.

O'Donnell, K. (2005). Japanese secondary English teachers: Negotiation of educational roles in the face of curricular reform. Language, Culture and Curriculum, 18(3), 300-315.

Okano, K., \& Tsuchiya, M. (1999). Education in contemporary Japan: Inequality and diversity. Cambridge: Cambridge University Press.

Pacek, D. (1996). Lessons to be learnt from negative evaluation. ELT Journal, 50(4), 335-343.

Sato, K. (2002). Practical understandings of communicative language teaching and teacher development. In S. J. Savignon (Ed.), Interpreting communicative language teaching (pp. 41-87). New Haven: Yale University Press.

Sato, K., \& Kleinsasser, R. C. (2004). Beliefs, practices, and interactions of teachers in a Japanese high school English department. Teaching and Teacher Education, 20, 797-816.

Sato, M., \& Asanuma, S. (2000). Japan. In P. Morris, \& J. Williamson (Eds.), Teacher education in the Asia-Pacific region: A comparative study (pp. 107-131). New York: Falmer Press. 
Scholefield, W. (1997). An overview of the teaching and learning of English in Japan since 1945. Babel, 32(1), 16-20, 37-38.

Takaki, N. (2002). PIGATE: Affecting EFL teacher change from the grassroots level in Japan. The Teacher Trainer, 16(2), 5-10.

Wada, M. (2002). Teacher education for curricular innovation in Japan. In S. J. Savignon (Ed.), Interpreting communicative language teaching (pp. 31-40). New Haven: Yale University Press.

Wedell, M. (2003). Giving TESOL change a chance: supporting key players in the curriculum change process. System, 31, 439-456.

Yonesaka, S. (1999). The Pre-service training of Japanese teachers of English. Journal, 23(11). Retrieved from http://www.jalt-publications.org/tlt/ articles/1999/11/yonesaka 